\title{
TSG101 Gene
}

National Cancer Institute

\section{Source}

National Cancer Institute. TSG101 Gene. NCI Thesaurus. Code C21233.

This gene is involved in suppression of transcription and regulation of the cell cycle. It also plays a role in cell proliferation and survival. 